\title{
Announcement and call for papers
}

\section{EUSIDIC Conference 1985}

Every autumn, the European Association of Information Services (EUSIDIC) organizes an annual conference. This year, it is to be held in Bath, United Kingdom, on 29-31 October - under the theme "Information - the billion-dollar industry".

The technical sessions of this conference will address themselves to the rapid growth of electronic information services throughout a wide spectrum of science, management and industry. Papers are invited from EUSIDIC members. The conference will bring together information users, producers, distributors and policy makers. Participants from a diverse range of backgrounds and organizations will be attending the conference.

Presentations will be grouped under the following headings:

- industry perspective

- technology

- the marketplace

- economics and policies

Anyone wishing to receive further details of the conference should contact: Mrs. Helen L. Henderson, EUSIDIC Administrative Secretariat, P.O. Box 429, London W4 1UJ, UK; tel. (01) 546-7968; telex 825962.

Anyone wishing to contribute a paper should send details (provisional title and a brief summary) to the Program Chairman: Mme. Anne Girard, Centre de documentation, Institut français du petrole, 1-4 avenue de Bois Preau, 92506 Rueil Malmaison, France.

All papers should be in the English language. A 300-word abstract will be due by the end of August. 